\title{
Reading Classical Authors in Capgrave's Life of St Katherine
}

To characterise John Capgrave as a writer of 'literature' has been, until recently, to court controversy, if not outright dissent. In his foreword to the Early English Text Society's edition of Capgrave's Life of St Katherine, Frederick Furnivall spares no time to consider what, if any, literary merit might attach to the work, being instead concerned to provide a rather patronising author portrait before launching into an embittered attack upon Carl Horstmann's editorial decision-making; the text, it seems, is of no more than antiquarian concern. ${ }^{1}$ More recently M. C. Seymour dismisses Capgrave's literary credentials; his Life of St Norbert is described as his 'first attempt in verse...perhaps as an experiment in literary ambition', while St Katherine is at best 'neatly ordered and suitable for piously uncritical literates. Neither life,' he continues, 'has anything to recommend it to another audience and neither rises above the general mediocrity of the genre. ${ }^{2}$ Implicit in Seymour's criticism here is the question of genre, Capgrave being damned by his association with hagiography; the sanctity of his subject-matter, far from acting as a guarantee of quality, appears instead to condemn his work out of hand. ${ }^{3}$ Yet some scholars have taken rather more trouble to explore what claims Capgrave might have to be counted among his literary forebears and contemporaries, with a particular emphasis on his Life of St Katherine. Derek Pearsall has suggested that the St Katherine is deeply indebted to the style and conventions of English metrical romances, notably Havelok, yet he also concedes that it should in some respects be regarded as 'a continuation of the Chaucer-Lydgate tradition of embellished rhetorical hagiography' ${ }^{4}$ In a relatively brief survey of the form and style of Capgrave's text, Jane Fredeman notes verbal features such as repetition and syntactical balance, which she ascribes to a possible north-west Midlands source. She also notes that the St Katherine is 
distinguished by the development of character and the production of vivid, believable debate scenes, and nods towards the possibility of dramatic influences upon the latter; but she considers Capgrave's use of imagery, with one or two exceptions, to be generally repetitive and trite. ${ }^{5}$ Starting from the assumption of Chaucer's influence on fifteenthcentury writing, Mary-Ann Stouck assesses the same text in search of correspondences with Troilus and Criseyde but, despite pointing to a small number of broad similarities, admits that there are no substantive verbal echoes of Chaucer to be found in the text. Crucially she regards this as symptomatic of a broader failure of fifteenth-century hagiography, which mires Capgrave's work in the popular - and by implication, non-literary - conventions of romance. 'The discrepancy between the ambitious concept and its stylistic execution,' she asserts, 'is characteristic of much of Capgrave's century. It is a reminder of the fledgling state of English as a literary language'. ${ }^{6}$ The verdict is damning because, as a 'literary' writer, it seems that Capgrave is both too early and too late: too early, because English has not yet developed to a point where it can meet the demands of his subject; too late, because the towering example of Chaucer places an insurmountable pressure upon him to perform at a similar level, which he simply cannot hope to achieve. His decision to produce hagiographies simply makes matters worse, since for many scholars they represent a genre which can have no reasonable claim to literary merit.

The reality is, however, that relatively few scholars have given detailed attention to Capgrave as a writer of literature, preferring instead to adopt a cultural studies approach which involves mining his works - especially the Life of St Katherine - for their possible application to religious, social and political contexts. This is understandable, for the Katherine in particular provides much material which is apposite to the discussion of heresy, 
the rise of lay literacy, and political dissatisfactions in the fifteenth century. ${ }^{7}$ In this paper, by contrast, I propose to look again at Capgrave's claims to be considered a 'literary' writer, and like my above-mentioned predecessors I shall focus my attention on his Life of St Katherine. ${ }^{8}$ I have noted elsewhere his use of vivid imagery and sense of audience; ${ }^{9}$ here my attention is directed specifically towards what seems to me to be Capgrave's self-conscious desire to place himself within a tradition of authorship extending much further back than his immediate predecessor Chaucer, evidenced in his use of classical authors, especially Virgil. Crucially, this is an aspect of the text for which I have been able to find no precedent in other extant lives of the saint in Middle English. There is no evidence to point to an exemplar from which Capgrave might have worked, and which might therefore have furnished him with this classicising framework; the book in 'derk langage' to which he refers in the Prologue to Book I $(1,62)$, and from which he asserts his own text was drawn, has never been identified, if indeed it ever existed. The only other fifteenth-century life of comparable length is that found in Harvard University, Houghton Library MS Richardson 44, a manuscript which has been dated to the second quarter of the fifteenth century, and hence is contemporaneous with Capgrave's text. It includes a substantial vita, the content of which is very similar to that of Capgrave's version, although it is written in prose rather than rhyme royal stanzas. Among the extant lives, this text bears the most resemblance to Capgrave's, but it entirely lacks the permeation with classical reading which characterises his work. As such, comparisons between the two provide useful evidence for what I am claiming as Capgrave's distinctive approach.

At first glance the search for classical precedents in Capgrave's text might appear to yield relatively little of interest; indeed, with the exception of Book Four the references are few. 
Yet a closer examination suggests that Capgrave introduces them with a careful eye to their effect. For example, in Book Two, during the celebrated Marriage Parliament, the Prince of Paphon recommends that Katherine submit herself to a speedy marriage, adducing Ovid in support of his argument:

"It is bettir, my lady dere,

In sech a caas whan it mote nedis be doo,

To do it at onys than for to lyve in dwere [perplexity]

And for to abyde eythir yer or too.

Take ye no heed? Consyder ye not ther-too,

How Ovyde seyde and wrote it in his booke:

'Whan thing is newe bewar betyme and looke

For to amende it, for medecyn comyth ovyr late

Whan that the man is dead and hens i-goo'". (II, 575-83)

This is the kind of allusion we encounter frequently in medieval literary texts; it is perhaps particularly reminiscent of Chaucer's Wife of Bath's famous injunction to 'Redeth ovyde', as the Prince directs Katherine to a classical source and, incidentally, seeks to display his own learning. ${ }^{10}$ Chaucer, of course, is playing with his readers at this point; it is well known that the Wife of Bath has misread her Ovid, substituting Midas' wife for his barber in a story which appears to rebound upon its teller, as anyone who takes her advice and turns to the Metamorphoses will quickly discover. Such playfulness seems typically Chaucerian and we are well accustomed to his games. The same cannot be said for Capgrave, and yet I wish to suggest that he is attempting something similar. The 'booke' to which the Prince refers is 
Ovid's Remedia Amoris, and the section he goes on to quote is one which warns against hasty love - precisely the opposite advice to that which he is actually offering Katherine. ${ }^{11}$ The similarity to the Wife of Bath goes further, for the Prince misquotes his source to meet his own purposes. In Ovid's text the caution is against loving too readily, for once embroiled, the lover will find it difficult to free himself; the Prince, by contrast, uses the quotation to urge Katherine on to love, lest in hesitating she should lose her opportunity. As in Chaucer, so here the misused antique source undermines the person using it, at least for those readers who know their Ovid. The use of this strategy may suggest that Capgrave owes a greater debt to Chaucer than has previously been acknowledged, indulging in what Daniel Wakelin characterises as a particular type of English 'classicism' in the form of Chaucerian allusion. ${ }^{12}$ Yet it also demonstrates that Capgrave's knowledge of Ovid is sufficient to enable him to incorporate a quotation into his text precisely in order to indulge in this moment of gentle satire. Such moments are, admittedly, quite rare in the text, but even so their presence does lead us towards an impression of Capgrave working quite self-consciously within a literary tradition that includes both the recent example of Chaucer and the much more remote authors of the classical past.

As mentioned above, it is in Book Four of Capgrave's text that his indebtedness to classical sources is most apparent. This is surely no accident; Book Four recounts events after Katherine has returned from her mystical marriage to Christ, and includes an account of Maxentius' imperial power struggles which ultimately result in his arrival in Alexandria, before moving on to detail the early stages of his conflict with the saint. This is the first explicit introduction of Roman history and culture into the text, where it collides violently with the world of the newly-converted Katherine; it also contrasts sharply with the exotic, 
almost oriental, and highly civilised environment of her girlhood. The resulting clash of cultures brings about a distinct change of mood in Book Four, and thus it is perhaps appropriate that Capgrave should have recourse to Latin writers in particular at this point. At a superficial level we might regard this as the insertion of a little 'period colour'; more significantly, their presence allows him to create his own miniature culture shock within the text, challenging his readers with the juxtaposition of antique and Christian traditions. Nevertheless, it must be conceded that some of his references are brief and non-specific; twice he makes allusions to classical mythology, once in an early description of pagan ceremonies at the temple, and again much later during Katherine's debate with the fifty pagan philosophers (IV, 390-406 and 1517-47). The allusions may reveal some acquaintance with Ovid's Metamorphoses and Virgil's Aeneid, but deities and events are mentioned in such general terms that it is impossible to identify specific sources. They may not, indeed, refer directly to antique texts at all, but may simply reflect the ubiquitousness of such references in late-medieval English writing, which form a kind of common literary currency which is passed from hand to hand with no particular thought for origins. In contrast, there are other moments in Book Four which can be much more securely tied to classical precedents, and it is to these that I now turn.

Like the other books which make up his text, Book Four opens with a Prologue, which in this case serves the purpose of allowing some narrative time to pass before the action of the story resumes. Capgrave utilises this brief pause to insert his own authorial voice into the text in comments about contrasting approaches to labour and social responsibility among mankind, before turning to Katherine's newly Christianised way of life which, he asserts, epitomises diligent service to God and man. The Prologue is, however, most striking for the 
inventive use Capgrave makes of classical precedent, as he draws a parallel between mankind and the society of bees which is clearly indebted to the fourth book of Virgil's Georgics. Capgrave's Prologue opens by distinguishing two different types of 'erdely dwellers' in his contemporary world: those who are prepared to labour, and those who 'are not profitable' $(I V, 1,15)$. Men in these two categories he likens to bees, whether the industrious workers or the unproductive drones. It is important to emphasise that here Capgrave is stepping outside his narrative; he is not, at this moment, discussing the protagonists in his hagiography, but potentially real men and women such as he might have seen around him on the streets of Lynn. In this respect there is a clear correspondence with Virgil's mode of proceeding in the Georgics, in which the ostensible aim of informing a farmer about agricultural and arboricultural practices is directed to the wider issue of the welfare of society. In his poem Virgil locates the source of renewed welfare in a rejection of Rome's urban focus in favour of a return to productively working the land. ${ }^{13}$ Like Virgil, Capgrave is critical of those who, like the drones, 'ete and drynk, devowre eke and wast: | Thei labour noght but if it be at table' (IV, 16-17). These human drones contribute nothing practical to their communities, nor to wider society; worse, their indolence extends to the spiritual sphere, and they are unwilling to expend effort on any 'goostly occupacyoun' (IV, 26). ${ }^{14}$ This foray into social philosophy has no parallel in MS Richardson 44; the anonymous author of that text betrays no concern with life outside of his narrative, and thus observations on human nature have no place in his text, unless they impinge directly upon the life of his protagonist. 
Even Capgrave cannot sustain his philosophizing for long, and his attention soon returns to Katherine. Sustaining the bee imagery, he indulges in imaginative development of the metaphor:

On of these bees was this same qweene,

The mayd Kateryne, whech with besynesse

Of every floure whech was fayre to seene

Sokyd oute hony of gret holynesse,

Bare it to hyve, and there she gan it dresse -

For it wyll do servyse bothe to God and man.

That same lycoure whech sche gaderyd than,

This hony gadered sche fere and woundyr wyde:

In the lawe of nature laboured sche formest,

Where sche the vyces lerned to ley osyde

And vertues to chese as a clenly nest[.] (IV, 43-53)

It is instructive to read MS Richardson 44 at the same point:

of al be substaunce of hir faders lyflode she kept bot a lytell to hir self and all the remenaunt wyth al hir faders tresour she disposed to pe sustenaunce of pe pore I puple. She loued not to here or see eny playes or iapes or eny veyn or worldly wordes or songes bot oonly she zaf hir to study of holy scripture and pat wyth gret diligence... she kept pe clennes of hir virgynyte. And in pis wyse she dwelled in hir 
faders paleys full of alle vertues and graces as pe ryght dere and singlere spouse of almyghty god. (ff.20v-21r) $)^{15}$

The ideas conveyed in these passages are strikingly similar. In both, Katherine is seen doing good to the people: in MS Richardson 44, by distributing her inherited fortune to the poor; in Capgrave's text, by preparing the 'hony of gret holynesse' so that it might 'do servyse' to man. Likewise both describe Katherine as eschewing vices and acquiring virtues, while the 'clennes' of the virginity of the one is echoed in the 'clenly nest' of the other. Capgrave, however, chooses to give additional colour to this material by extending the bee metaphor of the Georgics; the study of Scripture becomes holy honey, and while the saint of MS Richardson 44 dwells in her father's palace, Capgrave's Katherine chooses to nest, bee-like, in her virtues. This is, I suggest, clear evidence of a specifically literary consciousness; having adopted Virgil's imagery, Capgrave recognises its potential as moral allegory to enrich his own narrative, and he develops it with genuine creativity. He is not, of course, entirely original in adapting the social life of bees to a religious context; Virgil's choice of language invites us to play with a possible connection when he opens his own exposition by promising to speak of the 'mellis caelestia dona' [heavenly gift of honey], while his later (erroneous) description of the asexual reproduction of bees - 'neque concubitu indulgent, nec corpora segnes | in Venerem soluunt' [they neither indulge in concupiscence nor sluggishly weaken their bodies in sexual love ] - is felicitously suited to appropriation to the life of a virgin saint. ${ }^{16}$ Nevertheless, the elaboration of the imagery is all Capgrave's own, and it is, I suggest, playful and surprising in its imaginative scope. Indeed, one could argue that Capgrave takes a further hint from Virgil; the application of the bee metaphor to one of the 
foremost saints of the western Christian Church shows him recognising the possibilities of 'comparing small with great' for his own artistic and didactic purposes. ${ }^{17}$

Much later in Book Four Capgrave turns to one of the most celebrated episodes in lives of St Katherine: her debate with fifty pagan philosophers. As I have already mentioned, this is characterised by a number of references to the classical gods as Katherine asserts the supremacy of the true Christian God over the pagan pantheon; but my real interest here lies in the speech of the saint just before the debate proper begins, in which she resolutely turns away from the classical authorities who had previously constituted her learning. ${ }^{18}$ The extract is rather lengthy, but is worth quoting in full.

I hafe left all my auctores olde,

I fonde noo frute in hem but eloquens.

My bokes be go, goven or elles solde.

Farwell Arystotyll, for full grete expens

Made my fadyr and had full grete diligens

To lerne me thi sotill bokes alle,

Of dyverse names as thu ded hem calle.

Of Omere eke hafe I take my leve,

With his fayre termes in vers and eke in prose

Ful erly sat I and eke full late at eve

To lerne the texte and to lern the glose -

I hafe chose bettyr, treuly, I not suppose

But wote full well. Farwell eke Ovyde; 
Thou loved full wele blynd Venus and Cupyde.

I hafe take leve of Esculape and Galyene

And of all her pryvy sergyng of nature.

I hafe a lessoun mech trewere to susteyne

And more directe to know creature.

Ye, Plato bokes eke I you ensure

We hafe do now, we schall nevyr more mete,

Ne him Phylystyoun, bothe phylosophyre and poete. (IV, 1324-44)

The range of authorities thus rejected is interesting in itself: Katherine mentions two philosophers, two poets and three physicians, the last of whom, Philistion, she also credits with poetical ability. Again a comparison with MS Richardson 44 is illuminating:

pe philosophye and disputynge of Omer, pe crafty sotyltees of Aristotel, the wyse fyndyngs of pryue pynges of Esculapie and Galien. and pe famous bokes of Philistion and Plato and of other auctors I haue vtterly reproued. (f.33r)

The substantive content of the two texts is almost identical; with the exception of Ovid, the same authors appear in each, a correspondence which exemplifies the close relationship between the two. In Capgrave's version, however, Katherine's farewell takes a more elaborate form; in her rejection of the authors she lingers long enough to recall the powerful personal associations conjured up by their names. Aristotle is not merely a philosopher, but one for the study of whom her father was prepared to go to great expense; knowledge of Homer's 'fayre termes' was acquired through long days and late nights of 
diligent application. The effect of this speech is significant. In the context of the narrative it provides some real depth to Katherine's character, offering us a glimpse of how she reflects upon her past experience. The insight thus gained helps transform her from generic saint, conventionally unencumbered by human concerns, into something approaching a realistic human being, in the not unusual situation of realising that something for which she has worked hard over many years must be relinquished. This concern for developing characterisation through the construction of interior consciousness appears elsewhere in Capgrave's text, notably during the Marriage Parliament in Book Two, and surely demonstrates his 'literary' intentions; ${ }^{19}$ more importantly, I suggest it invites the reader to rethink the very concept of sanctity. Rather than an omnipotent, untroubled and depersonalized attribute, it is revealed as a process of becoming, difficult to attain and requiring both assiduous attention and personal sacrifice. Thus the 'humanisation' of Katherine implicitly rejects the reification of sanctity in favour of a more active model which offers the reader genuine exemplarity; Capgrave seems to be suggesting that she is, in many ways, quite like the rest of us, and thus we can realistically strive to be more like her.

In addition, the speech contributes substantially to Capgrave's self-constitution as a writer, constructing an image of scholarly endeavour which reflects positively on Capgrave himself. It suggests a clear parallel between sanctity and literary endeavour as it subtly reminds the reader that learning, whether classical or otherwise, is not attained without considerable effort and sacrifice. This is a topos frequently encountered in medieval literary texts; for example, in The Parlement of Fowles Chaucer offers his readers something similar when he awakens at the end of his dream: 
I wook, and other bokes took me to

To rede upon, and yet I rede alway;

In hope, y-wis, to rede so som day

That I shal mete som thing for to fare

The bet; and thus to rede I nil not spare. ${ }^{20}$

Chaucer will not cease to read 'alway' in the hope that his books will reveal something worthwhile that will help him, and perhaps his own readers, 'to fare /The bet'. The image evoked here is one which demands both sympathy and respect from the audience, as the more usual pleasures of life are rendered subservient to the scholarly imperative, and it would surely appeal to Capgrave quite as much as to Chaucer himself. There is also, perhaps, an element of wistfulness in the tone of Capgrave's speech which supports the suggestion that it has some personal resonance for its author. Yet this is not to suggest that we should interpret these words as Capgrave's own valediction to classical learning; after all, the very persuasiveness of the tone employed suggests that the 'eloquens' of 'auctoures olde' is still very much at his disposal. Perhaps Capgrave is once again playing with his readers, deploying the rejection of classical learning motif whilst simultaneously undercutting it with a demonstration of the continued value of such learning. Notwithstanding her lingering farewell to classical authors, Katherine continues to utilise her rhetorical training in the ensuing debate with the philosophers, and arguably it is her persuasive power, quite as much as the logic of her argument, which enables her to triumph. The concept of sanctity is thus further problematized; if, as I suggest, it can be regarded as a process, then that process clearly embraces a range of adaptations and accommodations, including apparent reversals and contradictions, in order to move towards 
its goals. Furthermore, Capgrave appears to be proposing a model of sanctity which is inextricably bound up with rhetorical expertise and literary prowess - his own as well as Katherine's. Such an elision of saintly and literary concerns is strikingly original, but carries a very convincing logical force when emanating from the pen of Capgrave, a friar devoted to scholarship.

From the foregoing it will be clear that I am suggesting Capgrave had read Virgil's Georgics, or at least the fourth book, or a commentary thereon, as well as being acquainted with a number of other classical texts, perhaps including Virgil's Aeneid and the Metamorphoses and Remedia Amoris of Ovid; we must therefore ask how likely it was that he would have had access to such materials. Research undertaken by both Peter Lucas and Karen Winstead suggests that Capgrave undertook preliminary education at Norwich before progressing, first to London, and then to Cambridge; thus it is primarily to the libraries of the Austin Friars in these locations, as well as to that at Lynn, that we must look for evidence. ${ }^{21}$ Here of course we encounter an immediate problem; the fraternal libraries suffered in the same way as those of other religious institutions at the Dissolution, and records are correspondingly scanty. Moreover, there is at least some evidence to suggest that fraternal libraries may have been in decline even before the 1530s; as James Carley notes in relation to the Austin house at Cambridge, 'all indications suggest that by the time Leland visited the convent [in the mid-1530s] the library was in a state of total disarray', and the house had 'practically dissolved itself'. ${ }^{22}$ The result, he suggests, is that '[o]ur knowledge of [fraternal] libraries tends to be "off centre" and depends on the idiosyncratic tastes of individual collectors and annotators such as Leland himself.' ${ }^{23}$ This caution seems scarcely necessary, given the paucity of extant records; thus far I have been unable to identify any manuscripts 
containing classical literary materials which can be conclusively connected with Capgrave. The records from Norwich and London yield nothing of this kind, and unfortunately there seems to be no evidence at all relating to the Austins' library at Lynn. The records pertaining to Cambridge are now only recoverable in fragmentary form, many of the manuscripts from all the fraternal libraries in that city having been acquired by Cardinal Cervini at the Vatican by the mid-1540s; it may be that in the future a more substantial reconstruction of that library's contents will be feasible. ${ }^{24}$ This all seems deeply unpromising; fortunately it is certainly possible to point to some wider evidence suggesting that the Austin Friars were not averse to reading classical authors. We are fortunate that the catalogue of the order's library at York, drawn up in 1372, survives as Dublin, Trinity College MS D.1.17. ${ }^{25}$ It notes two copies of Virgil, both containing the Eclogues, Aeneid and Georgics, as well as Servius' commentaries on the two latter texts. These appear among a substantial collection of other classical writings which include the Aeneid, the Metamorphoses, and even the Remedia Amoris, indicative of the eclecticism of what we might now term the acquisition policy of the library. ${ }^{26}$ Humphreys suggests that the York collection is anomalous among mendicant libraries in England, and this may be so; yet given Carley's warning we should not, perhaps, accede too readily to this suggestion, since it may look anomalous simply because other records have been lost. In any case, the evidence is that at least some Austin Friars at York had access to the works of Virgil, Ovid and other classical authors, as well as to later commentaries. Given that it is also clear that Capgrave had quite detailed knowledge of some of these texts, notably Book Four of the Georgics, we must assume that at some stage in his career he was able to access them, and this could quite possibly have been during his studies in either London or Cambridge, the extant records (or lack thereof) notwithstanding. 
The potential availability of such classical texts might lead us to ask whether we can consider Capgrave as in some way a successor to the group of so-called 'classicising friars' of the fourteenth century, identified by Beryl Smalley. ${ }^{27}$ Smalley suggests that the activities of her group of friars was restricted in scope and duration; numbering only seven, they were drawn exclusively from the Dominican and Franciscan orders, and flourished for a short period between around 1320 and 1350. Subsequent work by Christopher Baswell suggests that we might wish to extend the period of activity of friars deeply concerned with classical scholarship by at least thirty years, based upon his examination of a detailed Aeneid commentary in British Library Additional MS 27304, dateable to the last two decades of the fourteenth century and probably localised to Norwich. ${ }^{28}$ Suggestively for this paper, his research indicates that a lively interest in the engagement with, and moral allegorisation of, classical literature may well have existed at a time and place in which John Capgrave was receiving his early education. I must emphasize that there is no evidence to suggest any direct contact between Capgrave and MS Additional 27304, or the writer of its commentary; nevertheless we can at least point to possible continuities between Smalley's 'classicising friars', the commentary in the Norwich manuscript, and Capgrave's own literary endeavours of the 1440s. In each case we encounter sustained and imaginative engagement with classical texts, and a desire to render them both comprehensible and relevant to contemporary concerns. If Carley's suggestion that the Cambridge Austins were reading classical Latin in the 1520 s is correct, then the tradition may in fact extend much further, requiring a quite radical reassessment of fraternal reading and writing in the later Middle Ages. $^{29}$ 
In conclusion, I wish to suggest that it is possible to make some rather firmer claims for the literary qualities of Capgrave's Life of St Katherine than have been made hitherto. By consciously utilising the precedents of classical authors in his own work he is laying down a marker, implicitly asking his readers to set him alongside those same authors and judge him accordingly. Admittedly sometimes the references are slight enough to be discounted as mere tags and space-fillers; however, this cannot be said of his use of the bee allegory from the Georgics. Here we have very clear evidence of Capgrave's capacity to develop a set of ideas in the service of his text, creating a sustained moral allegory which is both apt and imaginatively constructed. ${ }^{30}$ Daniel Wakelin suggests a tendency among fifteenth-century authors to use classical material 'to fatten their own style. It is,' he says, 'as if they wrote in togas. ${ }^{31}$ The image is memorable, and in many cases the accusation is justified, but in Book Four of the Life of St Katherine we cannot dismiss Capgrave's practice as the kind of donning of literary fancy dress that Wakelin seems to be imagining. ${ }^{32}$ Instead he thoroughly reworks the bee allegory, absorbing it into his own text so that it becomes a vivid and relevant part of his saint's life. It is also clear that he has grasped the wider philosophical implications of Virgil's text which he is able to apply to the ills of humanity in general, the classical exemplum becoming a possible guide to contemporary living. ${ }^{33}$

We should also consider the deft nod of the head which Capgrave gives to Chaucer in the delightful misreading of Ovid's Remedia Amoris in Book Two. The gesture in the direction of the Wife of Bath is neither heavy-handed nor ponderous; on the contrary, it is accomplished with exceptional lightness of touch, revealing an unexpected sense of humour. As I have suggested above, it is not unusual to encounter Chaucerian allusions in fifteenth-century English writing, and indeed the search for Chaucer's continued literary influence has fuelled 
much scholarly debate. ${ }^{34}$ In his exploration of humanist reading and writing in this period, Daniel Wakelin suggests that we might regard such allusions as 'slightly used, second-hand', when compared with texts which reveal direct and incontrovertible evidence of engagement with classical sources themselves. ${ }^{35}$ This may well be so; nevertheless my intention here is not to make the case for Capgrave as a humanist, but as a writer of literature. ${ }^{36}$ That being so, his deliberate development of Katherine's character in his narrative might be regarded as a sign of a specifically literary consciousness at work. Unlike many - perhaps most - hagiographers, Capgrave is clearly willing to resist the conventional constraints on invention imposed by the genre, being instead concerned to show his protagonist as a 'real' person, with interior thoughts and memories which colour her responses to the events which unfold around her. The result is that Katherine is not merely a saint to be marvelled at, but a young woman who inspires sympathy, admiration, and sometimes irritation to a degree which we might well expect from Chaucer, that most 'literary' of writers, but not necessarily from the friar whom Seymour considers to be a pedlar of hagiographical mediocrities. In his careful and subtle self-construction as an author, too, it is clear that Capgrave regards himself as some sense engaged in a similar activity to his literary predecessors, both recent and antique. Perhaps most important of all, he also offers a much more complex and nuanced model of sanctity than most of his predecessors, a model in which the protagonist and hagiographer are inextricably implicated in each other's endeavours. Both strive for perfection, encounter challenges and reversals, and find themselves using unexpected sources of knowledge and experience in pursuit of their aims. Writing the lives of saints has always been to some extent a sanctified act, a labour made holy by its subject-matter; but in Capgrave's hands this labour is elevated 
to new heights as he suggests that the sanctity lies in the scholarly application and literary skill of the author quite as much as in the holy example of Katherine herself.

1 'Forewords' in John Capgrave, The Life of St Katharine of Alexandria, ed. Carl Horstmann, EETS o.s.100 (London: Kegan Paul, Trench, Trübner and Co., 1983). pp.v-xxviii.

${ }^{2}$ M. C. Seymour, John Capgrave, Authors of the Middle Ages 11 (Aldershot: Variorum, 1996), p.221.

${ }^{3}$ Seymour is certainly not alone in his critique of hagiography; as Sarah Salih notes, the genre has long suffered from suggestions that it is 'too crude and too stereotypical', 'static and derivative', and its piety can be alienating to a modern secular reader: Salih, ed., $A$ Companion to Middle English Hagiography (Cambridge: D.S. Brewer, 2006), p.20.

${ }^{4}$ Derek Pearsall, 'John Capgrave's Life of St Katharine and Popular Romance Style', Medievalia et Humanistica, 6 (1975), 121-37 (123).

${ }^{5}$ Jane C. Fredeman, 'Style and Characterization in John Capgrave's Life of St Katherine', Bulletin of the John Rylands University Library of Manchester, 62 (1980), 346-87.

${ }^{6}$ Mary-Ann Stouck, 'Chaucer and Capgrave's Life of St Katharine', American Benedictine Review, 33 (1982), 276-91 (p.291).

${ }^{7}$ See, for example, Karen A. Winstead, 'Piety, Politics, and Social Commitment in Capgrave's Life of St Katherine', Medievalia et Humanistica, 17 (1991), 59-80, and 'Capgrave's Saint Katherine and the Perils of Gynecocracy', Viator, 25 (1994), 361-76; Anke Bernau, 'A Christian Corpus: Virginity, Violence, and Knowledge in the Life of St Katherine of Alexandria', in St Katherine of Alexandria: Texts and Contexts in Western Medieval Europe, ed. Jacqueline Jenkins and Katherine J. Lewis (Turnhout: Brepols, 2003), pp.109-30; and 
Sarah James, "'Doctryne and studie": Female Learning and Religious Debate in Capgrave's Life of St Katharine', Leeds Studies in English, n.s.36 (2005), 275-302.

8 John Capgrave, The Life of Saint Katherine of Alexandria, ed. Karen A. Winstead, TEAMS Middle English Texts Series (Kalamazoo: Medieval Institute Publications, 1999). All references will be given by book and line numbers in the text. My focus on this text is determined by restraints on time and space, rather than a dismissal of the possible literary qualities of Capgrave's other works.

${ }^{9}$ Sarah James, 'The verse saints' lives of John Capgrave and Osbern Bokenham', in $A$ Companion to Fifteenth Century Verse, ed. A. S. G. Edwards and Julia Boffey (Woodbridge: Boydell and Brewer, forthcoming).

${ }^{10}$ Geoffrey Chaucer, 'The Wife of Bath's Tale', in The Riverside Chaucer, ed. Larry D. Benson, 3rd edn (Oxford: Oxford University Press, 1987) I.982.

${ }^{11}$ Ovid, Remedia Amoris, in Amores, Medicamina Faciei Femineae, Ars Amatoria, Remedia Amoris, ed. E. J. Kenney (Oxford: Oxford University Press, 1995; first published 1961), II.9193.

12 Daniel Wakelin, Humanism, Reading, and English Literature 1430-1530 (Oxford: Oxford University Press, 2007), p.66.

${ }^{13}$ See, for example, W. Y. Sellar, 'Motives, Form, Substance, and Sources of the Georgics', in The Roman Poets of the Augustan Age: Virgil, 3rd edn (Oxford: Clarendon Press, 1897), pp. 174-98; 'Introduction', in Virgil, The Georgics, trans. L. P. Wilkinson (Harmondsworth: Penguin, 1982), pp. 20-26.

${ }^{14}$ Capgrave is here participating in a long tradition which emphasizes the moral or ethical purposes of poetry, for a discussion of which see Vincent Gillespie, 'From the twelfth 
century to c.1450', in The Cambridge History of Literary Criticism, vol. 2: The Middle Ages, ed. Alastair Minnis and lan Johnson, pp. 145-235 (pp.147-50).

15 In quoting from this manuscript I have silently expanded abbreviations, and have where necessary inserted minimal puntuation to aid comprehension.

${ }^{16}$ Virgil, Georgics, ed. R. A. B. Mynors (Oxford: Clarendon Press, 1990), Book IV, 1, 198-99.

17 Virgil's own comparison, 'si parua licet componere magnis' [if small may be compared with great], is between the activity of the bees and the Cyclopean work of forging thunderbolts under Mount Etna: Georgics, IV, I. 176.

${ }^{18}$ For a further example of this motif in hagiography, see the legend of St Eugenia in Jacobus de Voragine, The Golden Legend: Readings on the Saints, trans. William Granger Ryan, 2 vols (Princeton: Princeton University Press, 1993, II, p.165.

${ }^{19}$ See, for example, Katherine's long interior monologue, II, 155-96.

${ }^{20}$ Geoffrey Chaucer, The Parlement of Fowles in The Riverside Chaucer, ed. II.695-99.

Chaucer's emphasis on the need to continually strive, through reading, for greater knowledge echoes the urging of Baccaccio in ch. 12 of The Genealogy of the Gentile Gods: see Medieval Literary Theory and Criticism, c.1100-c.1375: The Commentary-Tradition, ed. A.J. Minnis and A.B. Scott, with the assistance of David Wallace (Oxford: Clarendon Press, 1988), pp.428-31.

${ }^{21}$ See Peter Lucas, From Author to Audience: John Capgrave and Medieval Publication (Dublin: University College Dublin Press, 1997), and Karen A. Winstead, John Capgrave's Fifteenth Century (Philadelphia: University of Pennsylvania Press, 2007), ch. 1. 
22 James P. Carley, 'John Leland and the Contents of English Pre-Dissolution Libraries: The Cambridge Friars', Transactions of the Cambridge Bibliographical Society, 9 (1986), 90-100 (p.91).

${ }^{23}$ Carley, p. 93. Thus, for example, Leland's somewhat erratic mode of recording items, and his demonstrable preference for the works of English writers, clearly skews his cataloguing endeavours.

${ }^{24}$ Neil Ker and Andrew Watson have identified a number of manuscripts from the Cambridge Austin Friars, many of which are now in the Vatican Library: see Medieval Libraries of Great Britain: A List of Surviving Books, ed. N. R. Ker, 2nd edition (London: Royal Historical Society, 1964); and the Supplement to the Second Edition, ed. Andrew G. Watson (London: Royal Historical Society, 1987). See also Neil R. Ker, 'Cardinal Cervini's Manuscripts from the Cambridge Friars', in Xenia Medii Aevi Historiam Illustrantia, ed. Raymundus Creytens and Pius Künzle, 2 vols (Rome: Edizioni di Storia e Letteratura, 1978).

${ }^{25}$ The existence of this manuscript was first noted by James H. Todd, 'Ancient Libraries Library of the Augustinian Eremites of York, Notes and Queries, 1 (1849), 83-84.

${ }^{26}$ The Friars' Libraries, ed. K. W. Humphreys, Corpus of British Medieval Library Catalogues, 1 (London: British Library, 1990).

${ }^{27}$ Beryl Smalley, English Friars and Antiquity in the Early Fourteenth Century (Oxford: Blackwell, 1960).

${ }^{28}$ Christopher Baswell, Virgil in Medieval England: Figuring the Aeneid from the twelfth century to Chaucer (Cambridge: Cambridge University Press, 1995), pp. 158-59.

${ }^{29}$ Carley, p. 91 . There is, of course, plenty of evidence for broader scholarly engagement with classical texts throughout the Middle Ages: see, for example, Minnis et al, eds, 
Medieval Literary Theory, especially ch. 8; Gillespie, 'From the twelfth century'; Kevin Brownlee et al, 'Vernacular literary consciousness c.1100-c.1500: French, German and English evidence', in The Cambridge History of Literary Criticism, vol. 2, ed. Minnis and Johnson, pp.422-71; Rita Copeland and Peter T. Struck, The Cambridge Companion to Allegory (Cambridge: Cambridge University Press, 2010), chs 10-11; James G. Clarke, Frank T. Coulson and Kathryn McKinley, Ovid in the Middle Ages (Cambridge: Cambridge University Press, 2011), chs 9-10.

${ }^{30}$ Brownlee et al note 'a firm belief in the importance of individual skill in the rewriting of received matter' among medieval writers manifesting a clear literary consciousness, a belief surely exemplified by Capgrave's practice: 'Vernacular literary consciousness', p.428. ${ }^{31}$ Wakelin, p. 63.

${ }^{32}$ For a brief but suggestive discussion of the fissure between surface and sentence in medieval writing, see Brownlee et al, 'Vernacular literary consciusness', pp. 445-47. ${ }^{33}$ For a politicised reading of this type of exemplarity, see Wakelin's discussion of William Worcester's Boke of Noblesse, pp. 108-15.

${ }^{34}$ See, for example, the work of Stouck discussed above.

${ }^{35}$ Wakelin, pp. 65-66.

${ }^{36}$ Arguably Capgrave's use of the Georgics as described in this paper might lend some weight to the suggestion that he be considered a humanist writer, but a much broader assessment of his works would be necessary before any such argument could be sustained. 